\title{
ARTYKULY
}

\section{Agnieszka BARTOSZEWICZ*}

\section{RELIGIJNOŚĆ MIESZKAŃCÓW PÓŹNOŚREDNIOWIECZNEGO SZADKU W ŚWIETLE AKTÓW ICH OSTATNIEJ WOLI}

Streszczenie. W szadkowskich zapiskach radzieckich i wójtowsko-ławniczych znajdują się 42 akty ostatniej woli (z lat 1446-1502), co jest znaczącą liczbą, m.in. w porównaniu z sąsiednimi miastami. W artykule wykorzystane zostały również informacje o czterech pojedynczych legatach pobożnych, nie mających charakteru testamentów, ale pokazujących istotne rysy pobożności mieszczańskiej. W sumie analizowany materiał badawczy obejmuje dyspozycje wydane przez 61 mieszczan (część zapisów była sporządzona wspólnie przez małżeństwa). Wyniki kwerendy przeprowadzonej w aktach miejskich potwierdzają wcześniejsze ustalenia dotyczące relatywnie wysokiego poziomu kultury pisma mieszkańców późnośredniowiecznego Szadku, a także pozwalają lepiej poznać procedury spisywania testamentów i rolę władz miejskich jako organu nadzorującego tego rodzaju działania. Beneficjentem zapisów pobożnych dokonanych przez mieszczan z Szadku był przede wszystkim miejscowy kościół parafialny.

Forma analizowanych testamentów wskazuje, że sporządzenie testamentu było dla mieszkańców miasta przede wszystkim wydarzeniem odbywającym się w sferze kultury żywego słowa. Sporządzenie zapisu było czynnością wtórną, czasami dokonywaną już po śmierci darczyńcy, przy czym skupiano się na istocie dyspozycji, którym był dosyć często zapis na cele religijne. Różnorodność legatów i liczba zapisów informujących o nich w aktach miejskich nie może być uznana za typową dla małego miasta. Stanowi to interesujące świadectwo poziomu kultury miejskiej Szadku, ośrodka małego, ale aktywnie uczestniczącego $\mathrm{w}$ procesach modernizacji zachodzących w piętnastowiecznym Królestwie Polskim.

Słowa kluczowe: Szadek, XV w., religijność mieszczan, parafia szadkowska

* Agnieszka Bartoszewicz, prof. dr hab., Instytut Historyczny Uniwersytetu Warszawskiego, 00-927 Warszawa, ul. Krakowskie Przedmiescie 26/28, e-mail: abartoszewicz@uw.edu.pl. 
Testamenty stanowią od dawna przedmiot żywego zainteresowania historyków, którzy podkreślają znaczenie tego rodzaju źródeł w badaniach nad historią społeczną i gospodarczą, demografią historyczną, a także dziejami kultury materialnej i tzw. mikrohistorii. Pisemne dyspozycje ostatniej woli są również cennym materiałem dla studiów nad kulturą umysłową i mentalnością. Wielokrotnie podkreślano ich znaczenie w poznawaniu religijności różnych grup społecznych i poszczególnych osób, ponieważ jako wyraz świadomego przygotowywania się do śmierci testamenty stanowią ważne (a często jedyne) świadectwo stanu i form pobożności osób je sporządzających ${ }^{1}$. Zapisy na rzecz Kościoła są godnym uwagi przykładem stosowania zasad chrześcijańskiej dobroczynności, działalności fundacyjnej i charytatywnej z jednej strony, a z drugiej dowodzą pewnej wiedzy religijnej i wiary, że taka darowizna stanowi swego rodzaju inwestycję w życie pośmiertne ${ }^{2}$. Od dawna dostrzegany jest także związek instytucji testamentu z tzw. religion civique, zespołem zjawisk charakterystycznych dla średniowiecznych ośrodków miejskich i pobożności ich mieszkańców ${ }^{3}$.

Literatura przedmiotu poświęcona różnym aspektom funkcjonowania testamentu w średniowiecznym społeczeństwie, w tym mieszczańskiej pobożności, jest ogromna ${ }^{4}$. W wypadku polskich miast uwaga badaczy skupiała się jednak przede wszystkim na dyspozycjach ostatniej woli sporządzanych przez mieszkańców największych ośrodków: Krakowa, Gdańska, Torunia czy Poznania ${ }^{5}$.Znacznie rza-

1 A. Adamska, Stąd do wieczności. Testament $w$ perspektywie piśmienności pragmatycznej na przełomie średniowiecza i epoki nowożytnej, „Kwartalnik Historii Kultury Materialnej” 2013, t. 61, nr 2, s. 185 .

2 Ostatnio na ten temat J. Wysmułek, Testamenty mieszczan krakowskich (XIV-XV wiek), Wyd. Polskie Towarzystwo Historyczne, Wyd. Neriton, Warszawa 2015, s. 250 nn. Por. też E. Piwowarczyk, Legaty testamentowe ad pias causas w XV-wiecznym Krakowie. Z badań nad pobożnościa miejska, Wyd. Drukarnia Akcydensowa Dorosz Andrzej, Kraków 2010, s. 26 nn.

3 O religijności miejskiej (religion civique) i jej charakterze ostatnio J. Wysmułek, Testamenty mieszczan krakowskich, s. 314 nn. Tam wcześniejsza literatura przedmiotu.

4 Omawia ją J. Wysmułek, tamże, s. 23-31.

5 M.in. J. Wysmułek, Testamenty mieszczan ...; E. Piwowarczyk, Legaty testamentowe...; P. Oliński, Fundacje mieszczańskie $w$ miastach pruskich $w$ okresie średniowiecza i na progu czasów nowożytnych (Chetmno, Toruń, Elbląg, Gdańsk, Królewiec, Braniewo), Wyd. Naukowe Uniwersytetu Mikołaja Kopernika, Toruń 2008; B. Możejko, Rozrachunek z życiem doczesnym. Gdańskie testamenty mieszczańskie z XV i początku XVI wieku, Wyd. Uniwersytetu Gdańskiego, Gdańsk 2010; I. Grzelczak-Miłoś, Mieszczaństwo poznańskie w świetle libri testamentorum, mpis, praca doktorska, Uniwersytet im. Adama Mickiewicza w Poznaniu, Poznań 2011, https://repozytorium.amu.edu.pl/bitstream/10593/990/1/Mieszcza\%C5\%84stwo\%20pozna $\%$ C5\%84skie $\% 20$ w\%20\%C5\%9Bwietle\%20Libri\%20testamentorum.pdf [dostęp: 3.04.2018]. 
dziej interesowano się testamentami mieszkańców mniejszych miast ${ }^{6}$. Tymczasem opublikowany ostatnio katalog Testamenty z ksiag sądowych małych miast polskich do $1525 \mathrm{roku}^{7}$ zawierający wyniki kwerendy w ponad 100 księgach miejskich z 42 ośrodków późnośredniowiecznego Królestwa Polskiego dowodzi, że w XV w. zwyczaj sporządzania aktu ultimae voluntatis stawał się coraz powszechniejszy także w mniejszych ośrodkach. Jednym przykładów potwierdzających tę tezę jest Szadek. W tamtejszych zapiskach radzieckich i wójtowsko-ławniczych ${ }^{8}$ zostały odnalezione 42 akty ostatniej woli, co jest znaczącą liczbą, m.in. w porównaniu $\mathrm{z}$ sąsiednimi miastami: $\mathrm{w}$ aktach sieradzkich znajduje się 27 testamentów spisanych w badanym okresie, warckich -6 , wieluńskich - tylko 1 . Więcej pisemnych rozporządzeń ostatniej woli zachowało się tylko w księgach kilku ośrodków małopolskich i ruskich (Kazimierz - ponad 108, Nowy Sącz - 50; Przemyśl - 49, Przeworsk -71), ale w większości zachowanych ksiąg miejskich są to mniejsze liczby: np. z akt miejskich Kleparza pochodzi 39 zapisów testamentowych, Bochni i Płocka - po 21, Proszowic - 18, Biecza - 13, Lublina-10, Radziejowa - 6; Olkusza - ${ }^{9}$.

Najstarszy z aktów ostatniej woli w aktach miejskich szadkowskich uwzględniony w katalogu Testamenty z ksiag sadowych spisano w 1446 r., ostatni - w 1502 r. ${ }^{10}$ Poza tym w niniejszym artykule wykorzystane zostały informacje o czterech pojedynczych legatach pobożnych, nie mających charakteru testamentów, ale pokazujących istotne rysy pobożności mieszczańskiej ${ }^{11}$. W sumie analizowany materiał badawczy obejmuje dyspozycje wydane przez 61 mieszczan (część zapisów była sporządzona wspólnie przez małżeństwa) ${ }^{12}$ oraz niejakiego Jakuba zwanego Biacz z Dobruchowa, wsi w powiecie szadkowskim ${ }^{13}$. Trudno z całym przekonaniem powiedzieć, czy był to jej mieszkaniec czy też pochodzący

6 Do wyjątków należą prace: U. Sowina, Najstarsze sieradzkie testamenty mieszczańskie z początku XVI w. Analiza źródtoznawcza, „Kwartalnik Historii Kultury Materialnej” 1991, t. 39, $\mathrm{nr}$ 1, s. 3-25; K. Warda, Testamenty mieszczan radziejowskich $w$ późnym średniowieczu $w$ świetle ksiag ławniczych i radzieckich, „Kwartalnik Historii Kultury Materialnej” 2013, t. 61, nr 2, s. 269-275; A. Łosowska, Pawet i inni pisarze przeworscy $w$ drugiej połowie XV wieku, „Miscellanea Historico-Archivistica" 2015, t. XXII, s. 89-105; T. Związek, Testament młynarza z Koła. Przyczynek do badań nad późnośredniowiecznym mtynarstwem na ziemiach polskich, „Średniowiecze Polskie i Powszechne” 2012, nr 5 (9), s. 154-169.

7 Testamenty z ksiag sadowych matych miast polskich do 1525 roku, opr. A. Bartoszewicz, K. Mrozowski, M. Radomski, K. Warda, red. A. Bartoszewicz, Warszawa 2017 (Katalogi testamentów mieszkańców miast z terenów Korony i Wielkiego Księstwa Litewskiego do 1795 roku, t. 5). Testamenty szadkowskie obejmują numery katalogowe 511-551.

8 Akta radzieckie i wójtowskie z lat 1401-1502, Archiwum Główne Akt Dawnych, Księgi miejskie Szadek, sygn. Szadek 1 (dalej: Szadek 1).

9 Testamenty z ksiag sądowych..., opr. A. Bartoszewicz, K. Mrozowski, M. Radomski, K. Warda, red. A. Bartoszewicz, s. 9-17.

10 Szadek 1, s. 46, 424-425.

11 Szadek 1, s. 3 (1442 r.), 188 (1459 r.), 201 (1460 r.), 276 (1466 r.).

12 Por. przyp. 32.

13 Szadek 1, s. 46 (1446 r.). 
stamtąd obywatel Szadku. Użyty w stosunku do jego osoby przydomek stanowy providus wskazuje jednak na przynależność do stanu mieszczańskiego. Ponadto urzędnicy miejscy uwierzytelnili wpisem do swych ksiąg testamenty czterech osób duchownych: urodzonych w Szadku: Jana plebana z Łaska, prezbiterów Piotra syna młynarki końskiej i Macieja Baro nacione ex Schadek, a także altarzysty Piotra Sikuckiego de Szvyenna, kapłana szadkowskiego bractwa maryjnego ${ }^{14}$.

Wyniki kwerendy przeprowadzonej w aktach miejskich nie tylko potwierdzają wcześniejsze ustalenia dotyczące relatywnie wysokiego poziomu kultury pisma mieszkańców późnośredniowiecznego Szadku ${ }^{15}$, ale także pozwalają lepiej poznać procedury spisywania testamentów i rolę władz miejskich jako organu nadzorującego tego rodzaju działania. Rozporządzenia ostatniej woli klientów urzędów szadkowskich (podobnie jak w innych ośrodkach) były rejestrowane w różny sposób. Trzeba jednak podkreślić, że tylko jeden z testamentów zanotowanych w księdze Szadku ma pełną formę instrumentu notarialnego i został sporządzony zgodnie z regułami ars dictaminis, przez notariusza publicznego Jakuba syna Mikołaja z Szadku, z formularzowymi zwrotami informującymi o zdolności testatora do podejmowania decyzji, wyznaczeniu wykonawców jego dyspozycji, listą świadków etc. ${ }^{16} \mathrm{~W}$ badanym materiale źródłowym dominują oświadczenia zapisane w księdze w formie jednej notki ${ }^{17}$ lub kilku osobnych ${ }^{18}$, często jednak określanych przez pisarzy miejskich jako testamentum. Większość z nich złożyły osoby zdrowe ${ }^{19}$, które stawiły się przed sądem ławniczym (iudicium bannitum particulare). Dwukrotnie dyspozycje ostatniej woli wpisano do księgi już po śmierci testatora, na podstawie zeznania świadków obecnych, jak się można domyślać, przy łożu chorego ${ }^{20}$.

Większość z testamentów i zeznań ostatniej woli zanotowanych w szadkowskich aktach miejskich zawiera różnego rodzaju dyspozycje ad pias causas ${ }^{21}$. Trzeba przy tym zauważyć, że relatywnie sporą liczbę oświadczeń stanowią zapiski typu reformatio, czyli wzajemne zapisy małżonków dokonane na wypadek śmierci, wyłącza-

14 Szadek 1, s. 123-124 (1454 r.), 137-138 (1456 r.), 184, 188 (1459 r.), 598 (1488 r.).

15 Przejawem tego była m.in. duża liczba pochodzących studentów Uniwersytetu Krakowskiego pochodzących z Szadku, T. Marszał, Szadek. Monografia miasta, Wyd. Zarząd Miasta i Gminy Szadek, Szadek 1995, s. 26; A. Bartoszewicz, Późnośredniowieczny Szadek i jego mieszkańcy w świetle zapisek z najstarszej księgi miejskiej, „Biuletyn Szadkowski” 2006, t. 6, s. 119-120. Biogramy uczonych wywodzących się z Szadku: T. Marszał, Szadkowski słownik biograficzny. Średniowiecze i renesans, Wyd. Uniwersytetu Łódzkiego, Łódź 2012.

16 Szadek 1, s. 598 (1488 r.).

17 Szadek 1, s. 46 (1446 r.), 107 (1452 r.), 141 (1456 r.), 364 (1469 r.).

18 Np. testamenty Piotra Sikuckiego (1459 r., Szadek 1, s. 184) i Macieja Fary i jego żony (1466 r., tamże, s. 326).

19 Sanus mente et corpore, Szadek 1, s. 184 (1459 r.), 326 (1466 r.), 364 (1469 r.), 444 (1477 r.).

20 Szadek 1, s. 502 (1483 r.), s. 530 (1486 r.).

21 Żadnych legatów pobożnych nie zawierają testamenty rajcy Mikołaja Michty, kuśnierza Stefana Kupsza i Jana Tomkowicza, Szadek 1, s. 328 (1466 r.), 554 (1488 r.), 622 (1494 r.). 
jące $\mathrm{z}$ dziedziczenia krewnych, ale zawierające postanowienie, że na cele pobożne przeznaczone zostaną wszystkie dobra pozostałe po śmierci obojga testatorów ${ }^{22}$.

Nie jest żadnym zaskoczeniem, że beneficjentem zapisów pobożnych dokonanych przez mieszczan z Szadku był przede wszystkim miejscowy kościół parafialny $^{23}$. $\mathrm{Z}$ analogiczną sytuacją mamy bowiem do czynienia także $\mathrm{w}$ innych ośrodkach zarówno większych, jak i mniejszych ${ }^{24}$. We wszystkich miastach życie religijne toczyło się w kręgu fary i było organizowane przez plebana i podległych mu duchownych ${ }^{25}$, a ponadto tu znajdowało się najbardziej prestiżowe miejsce ostatniego spoczynku. Trzeba przy tym zauważyć, że świątynia parafialna w Szadku nie miała konkurencji w postaci klasztoru, który z pewnością byłby przedmiotem dobroczynności testatorów. Topografię kościelną piętnastowiecznego Szadku tworzyły poza farą: szpital, przy którym znajdował się cmentarz wraz kościołem pod wezwaniem Bożego Ciała. Ze szpitalem, także określanym jako hospitale Corporis Christi ${ }^{26}$, związane było bractwo religijne, którego patronką była Najświętsza Maria Panna ${ }^{27}$. Wszystkie te instytucje religijne otrzymywały różnego rodzaju darowizny jednak zdecydowanie rzadziej i mniejszej wartości niż świątynia parafialna ${ }^{28}$.

Legaty na rzecz szadkowskiej fary mają różną formę, a wzmianki o nich dowodzą, że silna więź z kościołem parafialnym przejawiała się już w sferze nazewnictwa. Pisarze, chyba w ślad za klientami urzędu, określali farę po prostu jako kościół lub kościół szadkowski: ecclesia, ecclesia Schadkoviensis, templum.

${ }^{22}$ Więcej na ten temat: A. Bartoszewicz, Wstęp, [w:] Testamenty z ksiag sadowych..., oprac. A. Bartoszewicz, K. Mrozowski, M. Radomski, K. Warda, red. A. Bartoszewicz, s. 18-19. Por. też przyp. 32.

${ }_{23}$ Pod wezwaniem Wniebowzięcia NMP i św. Jakuba. Por. P. Szkutnik, Parafia szadkowska na poczatku XVI wieku w świetle Liber Beneficiorum Jana Łaskiego, „Biuletyn Szadkowski” 2013, t. 13 , s. $65-80$.

${ }^{24}$ E. Piwowarczyk, Legaty testamentowe..., s. 101-136; E. Piwowarczyk, Pobożność krakowskich mieszczan w świetle ich testamentowych legatów z lat 1501-1530, „Saeculum Christianum: pismo historyczno-społeczne” 2011, nr 18/2, s. 84-89; U. Sowina, Najstarsze sieradzkie testamenty..., s. 21; K. Warda, Testamenty mieszczan ..., s. 272. Zapisy na rzecz kościoła parafialnego występują regularnie w testamentach mieszczan z Warty, Archiwum Główne Akt Dawnych, Księgi miejskie Warta, sygn. Warta 1, s. 208-210 (1493 r.), 439 (1507 r.).

25 H. Zaremska, Miasto: struktury społeczne i styl życia, [w:] Kultura Polski średniowiecznej. $X I V-X V$ w., red. B. Geremek, Wyd. Semper, Warszawa 1997, s. 206.

26 Szadek 1, s. 188 (1459 r.).

27 Na tyłach szpitala, koło cmentarza Bożego Ciała znajdował się dom wybudowany przez rajcę Benedykta Bakałarza dla kapelana bractwa NMP, Szadek 1, s. 538 (1457 r.). W 1540 r. erygowano prepozyturę szpitalną pod wezwaniem Trójcy Św., Bożego Ciała, św. Hipolita i św. Leonarda, P. Szkutnik, Źródła do dziejów Szadku znajdujace się w archiwach kościelnych, „Biuletyn Szadkowski" 2005, t. 5, s. 114.

28 Pominięto $w$ tych rozważaniach kościół św. Idziego, znajdujący się poza miastem i nie wzmiankowany w aktach miejskich Szadku z badanego okresu, por. A. Bartoszewicz, Późnośredniowieczny Szadek i jego mieszkańcy w świetle zapisek z najstarszej księgi miejskiej, „Biuletyn Szadkowski" 2006, t. 6, s. 118. 
Doprecyzowanie nazwy - wezwanie kościoła - podawano dopiero wtedy, gdy chodziło o świątynię Bożego Ciała. Najczęściej testatorzy zapisywali nieruchomości lub mniejsze bądź większe (na ogół większe) kwoty w gotówce na bieżące potrzeby kościoła, określane pro fabrica ecclesie ${ }^{29}$, pro structura ecclesie, super templum, super ecclesiam. Np. Jan Sirek przeznaczył na ten cel jedną grzywnę, ksiądz Piotr, syn młynarki końskiej - 3 grzywny, Dorota Strzeżyprogowa -4 grzywny, Barbara Osieczkówna - 2 grzywny, burmistrz Maciej Fara - aż 20 grzywien ${ }^{30}$. Z kolei Mikołaj Szomla i jego żona Dorota oddali pro fabrica ecclesie swój dom, ławnik Wawrzyniec Szkudlik - połowę domu wraz z wyposażeniem oraz wszystkie należne mu wierzytelności, Stanisław Kłopot - pieniądze pozyskane w wyniku sprzedaży domu, Jan Janek - podmiejskiej posiadłości (allodium). Hojnego zapisu dokonała Hanna żona Grzegorza Bazylicha, zapisując świątyni parafialnej dom i pole ${ }^{31}$. Równie szczodre, choć niekonkretne darowizny na rzecz kościoła szadkowskiego zostały odnotowane w formie klauzul do zapisów wzajemnych małżonków, którzy po śmierci obojga zainteresowanych nakazywali oddać cały majątek profabrica ecclesie $e^{32}$. Analogiczny charakter ma akt ostatniej woli Doroty Kujawczowej. Ta zamożna mieszczanka dom wraz z całym wyposażeniem zapisała dożywotnio swemu mężowi, ale z zastrzeżeniem, że po jego śmierci majątek ma trafić do szadkowskiego kościoła ${ }^{33}$.

Obok ogólnych zapisów pro fabrica ecclesie w dyspozycjach ostatniej woli mieszczan z Szadku znalazły się także legaty przeznaczone na konkretne cele związane z kościołem parafialnym, np. na odprawienie mszy (Jan Sirek, Jan Siwek $^{34}$ ). Te zapisy są dosyć lakonicznie sformułowane, np. jedna grzywnę kapłanom na odprawianie mszy ${ }^{35}$. Można jednak uznać, że chodzi tu o nabożeństwa za duszę zmarłego testatora, tzw. trycezymy, czyli odprawienie 30 mszy żałobnych $^{36}$. Nabożeństwa, a zatem modlitewna pamięć o testatorze, była też celem darowizny dokonanej przez księdza Piotra, syna młynarki końskiej, który dochody

29 Określenie pro fabrica ecclesie mogło oznaczać zarówno konkretne prace budowlane, jak i ogólne potrzeby kościoła, E. Piwowarczyk, Legaty testamentowe ..., s. 310.

30 Szadek 1, s. 107 (1452 r.), 124 (1454 r.), 327 (1466 r.). Dla porównania - pole wielkości 4 zagonów było warte 17 grzywien, dom -8 grzywien, Szadek 1, s. 328, 330 (1466 r.).

31 Szadek 1, s. 326-327 (1466 r.), 450 (1478 r.), 502 (1483 r.), 530 (1486 r.), 578 (1490 r.).

32 Zapisy wzajemne małżonków Mikołaja i Katarzyny Szyszków, Jana i Anny Ogonkowiczów, Marcina i Doroty Kozów, Jana i Anny Czechów, Jana i Małgorzaty Wospinków, Stanisława i Anny Smilszów, Michała i Małgorzaty, Wojciecha i Katarzyny Ryszów (Rysiów), Piotra i Doroty Pietrigów, Jakuba i Jadwigi Wiącheczów, Jana i Jadwigi Bujałów, Jana i Agnieszki, Stanisława i Agnieszki Jardulów, Anny i Wojciecha Piłatów, Jana i Anny Proczów, Jana i Małgorzaty Kryczków, Andrzeja i Doroty Liabrzuszków, Macieja i Doroty Farów, Szadek 1, s. 431 (1475 r.), 491-496, 498 (1483 r.), 500-501 (1484 r.), 529 (1486 r.), 553 (1488 r.), 565-566 (1489 r.), 577 (1490 r.), 609 (1493 r.), 635-636 (1497 r.), 653 (1499 r.), 424-425 (1502 r.).

33 Szadek 1, s. 648 (1499 r.).

34 Szadek 1, s. 107 (1452 r.), s. 444 (1475 r.).

35 ....unam [marcam] sacerdotibus pro celebracione missarum, Szadek 1, s. 107 (1452 r.).

36 E. Piwowarczyk, Legaty testamentowe..., s. 33. 
z jatki przeznaczył na uposażenie dla kapłana sprawującego liturgię̨ ${ }^{37}$. Popularną formą legatu - obecną we wszystkich miastach, zwłaszcza tych większych - było przeznaczenie gotówki bądź określonych dóbr materialnych na sporządzenie kielichów do kościoła czy dla konkretnego kapłana. Troje spośród szadkowskich testatorów (Piotr syn młynarki końskiej, Katarzyna wdowa po Bodzieczu, Jan Siwek ) zdecydowało się na taką fundację, która jednocześnie uświetniała liturgię i upamiętniała testatora ${ }^{38}$. Trzeba przy tym zauważyć, że w badanym materiale źródłowym widoczny jest specyficzny rodzaj legatu polegający na przekazaniu rzeczy należących do osobistego majątku testatora, tzw. gerady (w wypadku kobiet) lub hergewetu (w wypadku mężczyzn), w celu wykonania z nich przedmiotów służących liturgii, przede wszystkim kielichów i ornatów ${ }^{39}$. Tak właśnie postąpiła mieszczanka szadkowska Katarzyna Bodzieczowa, która przekazała 12 par sprzączek i 30 srebrnych guzików na sporządzenie kielicha do kościoła parafialnego ${ }^{40}$. Tego typu zapisy być może miały jeszcze jeden cel, mianowicie były związane z pewną formą myślenia magicznego i chęcią zapewnienia poprzez ufundowany przedmiot kontaktu z sacrum ${ }^{41}$. Podobny charakter miałby także zapis dokonany przez Piotra Kanczkę (Kączkę? Kaczkę?), który ufundował obraz dla kościoła Bożego Ciała, przedstawiający Matkę Boską z krzyżem² ${ }^{42}$.

We wszystkich testamentach mieszczańskich regularnie pojawiają się zapisy na rzecz szpitali, które stanowiły miejsce nieustannej modlitwy w intencji miasta i pozwalały realizować obowiązek chrześcijańskiego miłosierdzia. Często zakładano je z inicjatywy mieszczan, a zawsze były przedmiotem troski i dumy rajców i całej wspólnoty. Fundacje szpitalne i darowizny na rzecz mieszkających tam ubogich należą do charakterystycznych rysów religijności zarówno dużych ${ }^{43}$, jak i mniejszych ośrodków miejskich ${ }^{44}$. Szadek nie był wyjątkiem od tej reguły i darowizny pro hospitale są kilkakrotnie wzmiankowane w zapiskach urzędów miejskich. Burmistrz Maciej Fara przeznaczył na ten cel pieniądze ze sprzedaży ogrodu, Jan Tworzydło i Mikołaj Przytuła - domy, Jan Gromisz - pole ${ }^{45}$.

37 Szadek 1, s. 124 (1454 r.).

38 Szadek 1, s. 107 (1452 r.), 124 (1454 r.), 364 (1469 r.), 444 (1475 r.).

39 J. Wysmułek, Testamenty mieszczan ..., s. 276-284.

40 Szadek 1, s. 364 (1469 r.).

${ }^{41}$ Więcej na ten temat, J. Wysmułek, Testamenty mieszczan ..., s. 279-280.

42 Szadek 1, s. 276 (1466 r.). Wśród postanowień jego testamentu znalazł się także zapis czterech i pół grzywien w gotówce na rzecz tej świątyni.

43 Słoń M., Fundacje szpitalne władz komunalnych jako centra kultu miejskiego, [w:] Ecclesia et civitas. Kościól i życie religijne w mieście średniowiecznym, red. H. Manikowska, H. Zaremska, Wyd. Instytut Historii PAN, Warszawa 2002, s. 361-371.

44 U. Sowina, Najstarsze sieradzkie testamenty..., s. 21; K. Warda, Testamenty mieszczan..., s. 271; Z. Zyglewski, Religijność w miastach kujawskich późnego średniowiecza, [w:] Ecclesia et civitas.., s. 333-335.

45 Szadek 1, s. 325, 326 (1466 r.), 141 (1456 r.); Szadek 1, cz. 2 (składki luźne - Consularia), s. 102 (1467 r.). 
Charakterystyczne jest, że szadkowscy testatorzy, podobnie jak ci z innych ośrodków, najczęściej zapisywali na rzecz szpitala nieruchomości. Wynikało z bardzo praktycznych względów: dzierżawione domy, grunty orne czy ogrody przynosiły szpitalowi regularny dochód. Np. pole podarowane szpitalowi przez Jana Gromisza wydzierżawił burmistrz Maciej Fara, zobowiązując się płacić 20 groszy rocznego czynszu. Z kolei dom zapisany przez Mikołaja Przytułę miał co roku przynosić dochód w wysokości 16 groszy ${ }^{46}$. Oczywiście, nie wszystkie zapisy mogły być tak hojne, np. Jan Siwek podarował ubogim ze szpitala bliżej nieokreślone naczynie (sartago minor $)^{47}$. W testamentach można poza tym znaleźć zapisy pieniędzy na jałmużnę czy dla ubogich (pro pauperibus) ${ }^{48}$, co także należy rozumieć jako legat na rzecz szpitala. Czasami precyzyjnie określano przeznaczenie pieniędzy, np. Maciej Baro nakazał opłacić wspólny posiłek duchownych i ubogich (pro prandio pro presbiteris et pauperibus $)^{49}$. Podobnie szczegółowo sformułował swoje dyspozycje inny duchowny, altarzysta Piotr Sikucki, polecając za pieniądze uzyskane ze sprzedaży z dwóch łąk kupić drewno dla podopiecznych szpitala ${ }^{50}$.

Równie istotną jak szpital instytucją miejskiego życia religijnego były bractwa, korporacje religijne skupione wokół kościołów bądź właśnie szpitali. O działającym w Szadku bractwie pod wezwaniem NMP niewiele wiadomo, a zapisy na jego rzecz pojawiają się dosyć rzadko ${ }^{51}$. Nie ulega jednak wątpliwości, że przynajmniej jeden z jego kapłanów, Piotr Sikucki, pełnił ważną rolę w miejscowej społeczności, na tyle istotną, że Katarzyna wdowa po Grzegorzu Motyce podarowała mu ogród ${ }^{52}$. On sam z kolei sporządził dosyć oryginalny zapis, przeznaczając pieniądze pochodzące ze sprzedaży jatki dla osoby pełniącej funkcje kapelana bractwa, czyli siebie i swoich następców, w zamian za odprawianie mszy za jego i jego zmarłych rodziców ${ }^{53}$. Z działalnością bractwa być może należy także wiązać zapis jatki dokonany przez Piotra Żórawia na rzecz ołtarza w kościele pod wezwaniem Bożego Ciała i pełniącego przy nim posługę księdza Rafała ${ }^{54}$.

Wypada zadać sobie pytanie, czy wszystkie te dyspozycje były realizowane, a pieniądze i nieruchomości trafiały do kościołów, szpitala czy kapłanów. Na ogół chyba tak było, a znajdujące się w aktach ławniczych i radzieckich notki potwier-

46 Szadek 1, cz. 2 (składki luźne - Consularia), s. 102.

47 Szadek 1, s. 444 (1475 r.). Prawdopodobnie chodzi o naczynie do warzenia piwa, por. Mobilia. Inwentarze mienia ruchomego mieszczan krakowskich do schyłku XV wieku, Wyd. M. Starzyński, Kraków 2017, nr 52. Na ten temat także U. Sowina, Najstarsze sieradzkie testamenty..., s. 14.

48 Szadek 1, s. 141 (1456 r.), 327 (1466 r.).

49 Szadek 1, s. 598 (1488 r.).

50 Szadek 1, s. 184 (1459 r.).

51 Legat na msze za zmarłych członków bractwa, Szadek 1, s. 137-138 (1456 r.).

52 Szadek 1, s. 188 (1459 r.).

53 Szadek 1, s. 184 (1459 r.).

54 Szadek 1, s. 3 (1442 r.). Piotr Żóraw w innym miejscu księgi został określony jako oppidanus de Lasko et de Schadek, ibdem, s. 84 (1449 r.). 
dzają realizację zapisów ${ }^{55}$. Zdarzało się jednak, że testatorzy zmieniali swoje postanowienia, a Stanisław Kotliński, który pro fabrica ecclesie zapisał pół ogrodu, wyraźnie zaznaczył, że gdyby popadł w biedę, darowizna zostanie cofnięta, a ogród sprzedany ${ }^{56}$. Zmian w postanowieniach ostatniej woli dokonał również burmistrz Maciej Fara. Swój pierwszy zapis sporządził w 1466 r. i wówczas, jak już wspomniano, pieniądze ze sprzedaży ogrodu przeznaczył na potrzeby szpitala, a kościół parafialny miał otrzymać po śmierci jego i jego żony w sumie 20 grzywien (z czego 10 zapisanych na polu) ${ }^{57} .18$ lat później Maciej Fara z żoną (nie wiemy czy wciąż tą samą) sporządzili zapis na przeżycie, po śmierci legując cały majątek pro fabrica ecclesie Schadkoviensis ${ }^{58}$. Nie można jednak z całym przekonaniem stwierdzić, że zmiana ta oznaczała dla szadkowskiego szpitala stratę ogrodu, ponieważ notka z roku 1466 r. jest dość enigmatyczna i nie podano w niej wprost informacji, że darowizna ma być zrealizowana po śmierci darczyńcy. Nie można zatem wykluczyć, że pieniądze przekazano już w chwili sporządzania wpisu do akt.

W testamentach wpisanych do akt miejskich szadkowskich brakuje zapisów na rzecz kościołów znajdujących się poza terenem tego miasta, podczas gdy np. w aktach ostatniej woli mieszczan sieradzkich znalazły się zapisy dla bernardynów z pobliskiej Warty oraz kościołów parafialnych w Uniejowie, Grabnie i Kamionaczu ${ }^{59}$. Zapisy dla far znajdujących się poza miejscem zamieszkania są najczęściej dowodem więzi łączących wyrażających ostatnią wolę z miejscem pochodzenia ${ }^{60}$. Świadectwem takich powiązań jest zresztą legat Jana plebana z Łaska, pochodzącego z Szadku, na odprawienie mszy za zmarłych z bractwa NMP w rodzinnym mieście ${ }^{61}$. Przybysze, którzy nabyli w Szadku obywatelstwo (Jan z Dobruchowa, Piotr Żóraw), widocznie takich więzi nie odczuwali lub nie chcieli ich manifestować publicznie, wręcz przeciwnie podkreślali zapisem testamentowym związek z nowym miejscem zamieszkania. Ta obserwacja znajduje zresztą potwierdzenie w materiale źródłowym z innych ośrodków. W testamentach migrantów stosunkowo często znajdują się potwierdzenia asymilacji w postaci

55 Np. Szadek 1, s. 568 (1489 r.), informacja o realizacji zapisu dokonanego przez Stanisława Kłopota.

56 Szadek 1, s. 201 (1460 r.).

57 Szadek 1, s. 326.

58 Szadek 1, s. 500-501.

59 U. Sowina, Najstarsze sieradzkie testamenty..., s. 21.

60 Więcej na ten temat: U. Sowina, K. Pacuski, Testamenty mieszczan krakowskich jako źródła do badań nad stronami rodzinnymi imigrantów w krakowskiej elicie władzy (przykład Jana z Regut na Mazowszu), [w:] Elita władzy miasta Krakowa i jej związki z miastami Europy w średniowieczu i epoce nowożytnej (do połowy XVII wieku). Zbiór studiów, red. Z. Noga, Wyd. Antykwa, Kraków 2011, s. 433-446; J. Wysmułek, Testamenty mieszczan ..., s. 190-193.

${ }^{61}$ Szadek 1, s. 137-138 (1456 r.). 
hojnych legatów na rzecz miejscowych instytucji kościelnych ${ }^{62}$. W większym stopniu zastanawiać może brak legatów dla klasztorów znajdujących się w sąsiednich miastach ${ }^{63}$. Chodzi tu przede wszystkim o bernardynów z nieodległej Warty, zwłaszcza, że zachowały się wzmianki potwierdzające kontakty mieszczan szadkowskich zarówno z mieszkańcami tego miasta, jak i tamtejszym konwentem ${ }^{64}$.

Beneficjentami dobroczynności szadkowian były wyłącznie miejscowe instytucje kościelne, na co wpływ miały być może miejskie władze, przede wszystkim rada. Zachowany w piętnastowiecznych aktach miejskich Szadku materiał źródłowy odzwierciedla bowiem nie tylko proces recepcji instytucji testamentu w tym małym mieście, ale także pokazuje powielanie tu wzorów religion civique. Wyraźnie widoczne jest istnienie silnych więzi między sferą władzy i religii, przede wszystkim opieka rajców nad życiem religijnym mieszczan i przejmowanie przez nich nadzoru nad mieszczańskimi fundacjami pobożnymi ${ }^{65}$.

Władze miejskie odgrywały zasadniczą rolę zarówno podczas procedury sporządzania aktów ostatniej woli, jak i realizowania dyspozycji testatorów. W Szadku testamenty sporządzano przed sądami ławniczymi i wpisywano do księgi ławniczej ${ }^{66}$, jednak obecność rajców przy wszystkich tych działaniach jest wyraźnie widoczna. Po pierwsze, na ogół uczestniczyli w posiedzeniach sądów gajonych ${ }^{67} \mathrm{i}$ byli obecni przy ogłaszaniu dyspozycji ostatniej woli. Kilkakrotnie expressis verbis wymieniono ich jako świadków testamentu ${ }^{68}$. Po drugie, rajcy nadzorowali wykonywanie po-

${ }^{62}$ Przykładem może być wspomniany już (por. przyp. 24) testament Elżbiety Gawłowej z hojnymi zapisami dla kościołów w Warcie. Podobnie: Acta scabinalia Casimiriensia 1407-1427. Księga ławnicza kazimierska 1407-1427, Wyd. B. Wyrozumska, Kraków 1996, nr 324 (1408 r.); ANK, Akta miasta Krakowa, sygn. 428, s. 305 (1432 r.); A. Sochacka, G. Jawor (oprac.), Ksiega sadowa miasta Kamionki w ziemi lubelskiej 1481-1559, Archiwum Państwowe w Lublinie, Instytut Historii Uniwersytetu Marii Curie-Skłodowskiej, Lublin 2009, nr 101 (1501 r.).

63 Podczas gdy np. w testamentach mieszczan wąwolnickich znajdują się zapisy na rzecz lubelskiego konwentu bernardynów, Księgi sądowe miasta Wąwolnicy z lat 1476-1500, oprac. G. Jawor, A. Sochacka, red. R. Szczygieł, Wyd. Uniwersytetu Marii Curie-Skłodowskiej, Lublin 1998. $\mathrm{nr} 223,224$ (1497 r.).

${ }^{64}$ Zachowały się wzmianki o pochodzących z Szadku tercjarkach bernardyńskich, Szadek 1, s. 582 (1491 r.). O kontaktach między Szadkiem a Wartą, A. Bartoszewicz, Późnośredniowieczny Szadek..., s. 117.

${ }_{65}$ Por. J. Wysmułek, Testamenty mieszczan ..., s. 314-326.

66 Przy czym nie zawsze oświadczeniu ostatniej woli złożonemu przed ławnikami towarzyszyło sporządzenie zapisu. Świadczy o tym akt ostatniej woli Jana Gromisza wpisany do akt radzieckich z zaznaczeniem jednak, że testament został uczyniony przed ławnikami (fecit coram scabinis, Szadek 1, Consularia, s 102 (1467 r.) czy dyspozycje Mikołaja Szomli zanotowane później na podstawie zeznania ławników, tamże, s. 392 (1473 r.).

67 Np. Szadek 1, s. 123 (1459 r.), 184 (1459 r.), 193 (1460 r.), 328-330 (1466 r.). Nie było to jednak regułą, por. tamże, passim.

${ }_{68}$ Np. Piotr syn młynarki końskiej sporządził testament w obecności burmistrza, rajców i ławników, Szadek 1, s. 124 (1454 r.), Jan Tworzydło - w obecności rajców, tamże, s. 141 (1456 r.). Tylko w zapisie oświadczenia ostatniej woli altarzysty Piotra Sikuckiego zaznaczono, że został on sporządzony za zgodą wójta, Szadek 1, s. 184 (1459 r.). 
stanowień testatorów, zresztą zgodnie z ich wolą. Np. Piotr syn młynarki końskiej przekazał na ręce burmistrza i rajców nadzór nad jatką, z której dochody miały stanowić uposażenie dla kapelana, przez nich wybranego ${ }^{69}$, Jan Tworzydło - nad domem zapisanym na rzecz szpitala ${ }^{70}$. Podobnie uczynił burmistrz Maciej Fara powierzając rajcom realizację zapisów na rzecz kościoła i szpitala ${ }^{71}$. Rajcy mieli też w swojej pieczy dwa ogrody, z których dochody stanowiły uposażenie duchownego odprawiającego cotygodniowe msze za zmarłych członków bractwa maryjnego ${ }^{72}$.

Świadectwem związków szadkowskich elit władzy z instytucjami kościelnymi jest także $z$ jednej strony obecność miejscowego duchowieństwa w roli klientów sądu $^{73}$, a z drugiej - czynione przez księży zapisy ad pias causas. Plebani i wikariusze zapewniający posługę duszpasterską mieszczanom z Szadku byli bardzo często ich krewnymi, posiadali w mieście odziedziczone nieruchomości. Bywali zarówno beneficjentami mieszczańskiej pobożności, jak i sami występowali w roli testatorów. Jednocześnie, wspólnie z rajcami dbali o życie religijne w mieście i zapewne ich udział w sporządzeniu oświadczeń ostatniej woli miał wpływ na decyzje o darowiznach na rzecz Kościoła ${ }^{74}$. Wprawdzie nie mamy bezpośrednich wzmianek poświadczających obecność duchownych przy sporządzaniu testamentów przez osoby świeckie ${ }^{75}$, Wydaje się jednak, że jakiś ksiądz był obecny np. przy sporządzaniu aktu ostatniej woli przez chorego ławnika Wawrzyńca Szkudlika. Wskazuje na to formularz testamentu zawierający pewne elementy instrumentu notarialnego, a także informacja, że zapis został sporządzony w obecności świadków. Obecność osoby duchownej przy łożu umierającego, tym samym biorącej udział w ceremonii ogłaszania aktu ostatniej woli, byłaby zatem dosyć oczywista $^{76}$. Udział księży w tego rodzaju wydarzeniach potwierdza też informacja, że mieszczanka Małgorzata Kozłowa podarowała dom synowi Stefanowi w obecności burmistrza Pawła i księdza Rafała ${ }^{77}$. Skoro zatem w obecności duchownych ogłaszano darowizny o świeckim charakterze, to tym bardziej prawdopodobna jest ich obecność przy sporządzaniu zapisów ad pias causas.

69 Szadek 1, s. 124 (1454 r.).

70 Szadek 1, s. 141 (1456 r.).

71 Szadek 1, s. 326 (1466 r.).

72 Szadek 1, s. 137-138.

73 Np. Szadek 1, s. 33 (1445 r.), 49 (1446 r.), 94, 98 (1451 r.), 476 (1481 r.).

74 O wpływie spowiedników i innych osób duchownych na postanowienia testatorów m.in. K. Szende, Testamenty i ustne oświadczenia woli. Oralność i piśmienność w procesie sporzadzania testamentów na Węrzech w późnym średniowieczu, „Kwartalnik Historii Kultury Materialnej” 2013, t. 61, nr 2, s. 229.

75 Notujemy obecność prezbitera Michała przy składaniu oświadczenia ostatniej woli przez Piotra syna młynarki końskiej, także należącego do stanu duchownego oraz licznych duchownych towarzyszących sporządzaniu ostatniej woli przez prezbitera Michała Baro, Szadek 1, s. 123-124 (1454 r.), s. 598 (1488 r.).

76 Por. K. Szende, Testamenty i ustne oświadczenia..., s. 226-227.

77 Szadek 1, s. 7 (1437 r.). 
Nie możemy też wykluczyć, że naciski rajców, aktywnie zaangażowanych w opiekę nad majątkiem kościelnym nie pozostawały bez wpływu na decyzje o dokonaniu zapisu pobożnego. Trzeba przy tym zwrócić uwagę na znajdujące się w małżeńskich zapisach wzajemnych klauzule dotyczące przekazania po śmierci małżonków majątku na rzecz fary (super ecclesiam in Schadek, pro structura ecclesie Schadkoviensis). Tego rodzaju dyspozycje znajdujemy wprawdzie w księgach innych ośrodków miejskich, m.in. Sieradza, Przemyśla, Przeworska czy podkrakowskiego Kazimierza ${ }^{78}$. Wszędzie jednak zdecydowaną większość stanowią zapisy wzajemne nie mające tego rodzaju uzupełnień, podczas gdy w Szadku dominują posiadające zapis na rzecz świątyni ${ }^{79}$.

Powodem sporządzenia testamentu mogła być także chęć zapewnienia sobie pochówku w kościele parafialnym, co wyraźnie podkreślił w swoim oświadczeniu Jakub z Dobruchowa. Dla przybysza ze wsi była to sprawa szczególnie istotna i prestiżowa. Nie można także wykluczyć, że sporządzenie aktu ostatniej woli traktowano jako manifestację przynależności do kręgu elity miejskiej. Przy czym trzeba podkreślić, że w gronie testatorów spotykamy zarówno przedstawicieli władz miejskich (burmistrza Macieja Farę, rajców Mikołaja Michtę, Benedykta bakałarza, Macieja Wosprykę, ławników Jana Tworzydłę i Warzyńca Szkudlika), jak i mieszczan uboższych, nie pełniących żadnych funkcji urzędowych.

Motywacje, którymi kierowali się szadkowscy testatorzy rozporządzający swoim majątkiem, muszą jednak pozostawać w sferze interpretacji i domysłów. Analizowane dyspozycje ostatniej woli nie posiadają żadnych części wstępnych, w rodzaju dewocyjnych inwokacji czy areng zawierających refleksje nad przemijaniem oraz deklaracje chęci rozliczenia się ze światem żywych i zdobycia przepustki do nieba ${ }^{80}$. Sporadycznie tylko informowano o uczynieniu zapisu „,z powodu Boga” (propter Deum) czy „dla zbawienia duszy” (pro salute anime) ${ }^{81}$.

Otwartym pytaniem pozostaje także indywidualizm poszczególnych dyspozycji, ponieważ na ogół mieszczanie decydowali się na sporządzanie zapisów mieszczących się w określonym schemacie ${ }^{82}$. Należy jednak przyznać, że choć w oświadczeniach mieszczan szadkowskich dominują zapisy określone pro fabrica

78 A. Bartoszewicz, Wstęp, s. 19.

79 W Szadku oczywiście także sporządzano zapisy wzajemne bez klauzuli o przekazaniu majątku na rzecz Kościoła, np. Benedykt baccalarius z żoną Klarą, Szadek 1, s. 225-226 (1462 r.); Grabowski z żoną Elżbietą, tamże, s. 329 (1466 r.); Jan Schemek z żoną Małgorzatą, tamże, s. 329 (1466 r.); Maciej Wospryka z żoną Dorotą, tamże, s. 376-377 (1471 r.); Jan zwany Chanusz (sic) z żoną Dorotą, tamże, s. 501 (1484 r.).

80 E. Piwowarczyk, Legaty testamentowe..., s. 27.

81 Szadek 1, s. 46 (1446 r.), 201 (1460 r.).

82 O testamentach jako źródle pozwalającym badać przeżycia i mentalność osób wyrażających ostatnią wolę: por. W. Chorążyczewski, A. Rosa, Egodokumenty - egodokumentalność - analiza egodokumentu - spuścizna egodokumentalna, [w:] Egodokumenty. Tradycje historiograficzne i perspektywy badawcze, red. W. Chorążyczewski, A. Pacevičius, S. Roszak, Wyd. Naukowe Uniwersytetu Mikołaja Kopernika, Toruń 2015, s. 7-21. Tam wcześniejsza literatura przedmiotu. 
eccelsie czy super ecclesiam, obserwujemy w analizowanym materiale źródłowym stosunkowo znaczną rozmaitość legatów. Część testatorów dokonywała zapisów na wyraźnie sprecyzowane cele, takie jak fundacje mszalne, polecenia wykonania konkretnych przedmiotów (kielichy, obraz) upamiętniających darczyńcę, zapisy na rzecz ołtarzy i kapłanów, bardzo konkretne darowizny dla ubogich ze szpitala itp.

Obraz, jaki otrzymujemy w wyniku analizy zapisów ostatniej woli mieszkańców późnośredniowiecznego Szadku nie jest jednoznaczny. Z jednej strony forma analizowanych testamentów wskazuje, że sporządzenie testamentu było dla mieszkańców miasta przede wszystkim wydarzeniem odbywającym się w sferze kultury żywego słowa, swego rodzaju spektaklem, w którym brał udział testator, jego rodzina, świadkowie świeccy i duchowni. Sporządzenie zapisu było czynnością wtórną, czasami dokonywaną już po śmierci darczyńcy, przy czym skupiano się na istocie dyspozycji, którym był dosyć często właśnie zapis na cele religijne. W drugiej połowie XV w. tego rodzaju akty ostatniej woli są charakterystyczne dla mniejszych ośrodków, o agrarnym charakterze i stosunkowo niskim poziomie kultury pisma. Małomiasteczkowy charakter religijności mieszkańców Szadku potwierdzałaby także ograniczona liczba instytucji otrzymujących legaty i brak jakichkolwiek wzmianek o pielgrzymkach, dalszych (Kraków, Rzym) czy bliższych (Warta). Z drugiej strony, wyraźnie widoczna jest recepcja i powielanie w Szadku wzorów charakterystycznych dla religion civique i zaangażowanie władz miejskich w działalność instytucji religijnych. Podobnie jak w dużych miastach rajcy przejmowali opiekę nad fundacjami mieszczańskimi, wybierali kapłanów, którym powierzano sprawowanie liturgii, dbali o ich uposażenie. Różnorodność legatów i liczba zapisów informujących o nich w aktach miejskich także nie może być uznana za typową dla małego miasta. Stanowi dla nas tym samym interesujące

świadectwo poziomu kultury miejskiej Szadku, ośrodka małego, ale aktywnie uczestniczącego w procesach modernizacji zachodzących w piętnastowiecznym Królestwie Polskim.

\section{Bibliografia}

Adamska A., Stąd do wieczności. Testament w perspektywie piśmienności pragmatycznej na przełomie średniowiecza i epoki nowożytnej, „Kwartalnik Historii Kultury Materialnej" 2013, t. 61, nr 21, s. 185-200.

Bartoszewicz A., Późnośredniowieczny Szadek i jego mieszkańcy w świetle zapisek z najstarszej księgi miejskiej, „Biuletyn Szadkowski” 2006, t. 6, s. 111-126.

Bartoszewicz A., Wstepp, [w:] Testamenty z ksiag sadowych matych miast polskich do 1525 roku, Testamenty z ksiag sadowych malych miast polskich do 1525 roku, oprac. A. Bartoszewicz, K. Mrozowski, M. Radomski, K. Warda, red. A. Bartoszewicz, Wyd. Naukowe Semper, Warszawa 2017 (Katalogi testamentów mieszkańców miast z terenów Korony $i$ Wielkiego Księstwa Litewskiego do 1795 roku, t. 5), s. 7-27. 
Chorążyczewski W., Rosa A., Egodokumenty - egodokumentalność - analiza egodokumentu - spuścizna egodokumentalna, [w:] Egodokumenty. Tradycje historiograficzne i perspektywy badawcze, red. W. Chorążyczewski, A. Pacevičius, S. Roszak, Wyd. Naukowe Uniwersytetu Mikołaja Kopernika, Toruń 2015, s. 7-21.

Grzelczak-Miłoś I., Mieszczaństwo poznańskie w świetle libri testamentorum, mpis, praca doktorska, Uniwersytet im. Adama Mickiewicza w Poznaniu, Poznań 2011.

Łosowska A., Pawet i inni pisarze przeworscy $w$ drugiej połowie XV wieku, „Miscellanea Historico-Archivistica" 2015, t. XXII, s. 89-105.

Marszał T., Szadek. Monografia miasta, Wyd. Zarząd Miasta i Gminy Szadek, Szadek 1995.

Marszał T., Szadkowski słownik biograficzny. Średniowiecze i renesans, Wyd. Uniwersytetu Łódzkiego, Łódź 2012.

Możejko B., Rozrachunek z życiem doczesnym. Gdańskie testamenty mieszczańskie z XV i poczatku XVI wieku, Wyd. Uniwersytetu Gdańskiego, Gdańsk 2010.

Oliński P., Fundacje mieszczańskie $w$ miastach pruskich $w$ okresie średniowiecza $i$ na progu czasów nowożytnych (Chetmno, Toruń, Elblag, Gdańsk, Królewiec, Braniewo), Wyd. Naukowe Uniwersytetu Mikołaja Kopernika, Toruń 2008.

Piwowarczyk E., Legaty testamentowe ad pias causas $w X V$-wiecznym Krakowie. Z badań nad pobożnością miejska, Wyd. Drukarnia Akcydensowa Dorosz Andrzej, Kraków 2010.

Piwowarczyk E., Pobożność krakowskich mieszczan wświetle ich testamentowych legatów z lat 1501-1530, „Saeculum Christianum: pismo historyczno-społeczne” 2011, nr 18/2, s. 77-100.

Słoń M., Fundacje szpitalne władz komunalnych jako centra kultu miejskiego, [w:] Ecclesia et civitas. Kościót i życie religijne $w$ mieście średniowiecznym, red. H. Manikowska, H. Zaremska, Wyd. Instytut Historii PAN, Warszawa 2002, s. 361-373.

Sochacka A., Jawor G. (oprac.), Księga sądowa miasta Kamionki w ziemi lubelskiej 1481-1559, Archiwum Państwowe w Lublinie, Instytut Historii Uniwersytetu Marii Curie-Skłodowskiej, Lublin 2009.

Sowina U., Najstarsze sieradzkie testamenty mieszczańskie z początku XVI w. Analiza źródłoznawcza, „Kwartalnik Historii Kultury Materialnej” 1991, t. 39, nr 1, s. 3-25.

Sowina U., Pacuski K., Testamenty mieszczan krakowskich jako źródta do badań nad stronami rodzinnymi imigrantów w krakowskiej elicie władzy (przykład Jana z Regut na Mazowszu), [w:] Elita władzy miasta Krakowa i jej zwiazki z miastami Europy $w$ średniowieczu i epoce nowożytnej (do połowy XVII wieku). Zbiór studiów, red. Z. Noga, Wyd. Antykwa, Kraków 2011, s. 433-446.

Szende K., Testamenty $i$ ustne oświadczenia woli. Oralność i piśmienność w procesie sporządzania testamentów na Wegrzech w późnym średniowieczu, „Kwartalnik Historii Kultury Materialnej” 2013, 61, nr 2, s. 223-238.

Szkutnik P., Parafia szadkowska na początku XVI wieku w świetle Liber Beneficiorum Jana Łaskiego, „Biuletyn Szadkowski” 2013, t. 13, s. 65-80.

Szkutnik P., Źródła do dziejów Szadku znajdujace się w archiwach kościelnych, „Biuletyn Szadkowski” 2015, t. 5, s. 111-127. 
Testamenty z ksiag sądowych matych miast polskich do 1525 roku, oprac. A. Bartoszewicz, K. Mrozowski, M. Radomski, K. Warda, red. A. Bartoszewicz, Warszawa 2017 (Katalogi testamentów mieszkańców miast z terenów Korony i Wielkiego Księstwa Litewskiego do 1795 roku, t. 5).

Warda K., Testamenty mieszczan radziejowskich $w$ późnym średniowieczu $w$ świetle ksiag ławniczych i radzieckich, „Kwartalnik Historii Kultury Materialnej” 2013, t. 61 , nr 2, s. 269-275.

Wysmułek J. , Testamenty mieszczan krakowskich (XIV-XV wiek), Wyd. Polskie Towarzystwo Historyczne, Wyd. Neriton, Warszawa 2015.

Zaremska H., Miasto: struktury społeczne i styl życia, [w:] Kultura Polski średniowiecznej. XIV-XV w., red. B. Geremek, Wyd. Semper, Warszawa 1997, s. 189-238.

Zyglewski Z., Religijność w miastach kujawskich późnego średniowiecza, [w:] Ecclesia et civitas. Kościót i życie religijne w mieście średniowiecznym, red. H. Manikowska, H. Zaremska, Wyd. Instytutu Historii PAN, Warszawa 2002, s. 327-345.

Związek T., Testament mlynarza z Koła Przyczynek do badań nad późnośredniowiecznym mlynarstwem na ziemiach polskich, „Średniowiecze Polskie i Powszechne” 2012, nr 5 (9), s. 154-169.

[Artykuł wpłynął: kwiecień 2018; akceptacja: sierpień 2018]

\section{RELIGIOUSNESS OF SZADEK INHABITANTS IN THE LATE MIDDLE AGES IN THE LIGHT OF THEIR TESTAMENTS}

\section{Summary}

The municipal records in Szadek contain 42 testaments from the period 1446-1502, which is a considerable number compared with e.g. the neighbouring cities. There also is information about four bequests that do not have the character of testaments, but are indicative of the main traits of the citizens' religiousness. The analysed material comprises dispositions given by 61 burghers (some of the legacies were done jointly by married couples). The parish church was the main beneficiary of the bequests for religious purposes (which were quite frequent).

The form of the analysed testaments shows that they were made orally, while the written version was secondary, and was sometimes made after the donor's death. The great variety of the bequests and the number of entries informing about them in city records cannot be regarded as typical of a small town. It is an interesting evidence of the high cultural level of Szadek - a town small but actively participating in modernization processes taking place in the $15^{\text {th }}$ century in the Kingdom of Poland.

Keywords: Szadek, the $15^{\text {th }}$ c., religiousness of town dwellers, the parish of Szadek 